\title{
Combination of Persulfate /Peroxymonosulfate Activated By Ion (II) with Hydrogen Peroxide for Mineralization and Valorization of Vinasse
}

\author{
Mohamed Awad Fagier 1,*iD, Mohammed Salaheldeen ${ }^{2}$, Mona O. Abdalrhman ${ }^{3}$ \\ Department of Chemistry, Faculty of Education, University of Blue Nile, Sudan; mfagery@yahoo.com; \\ Department of Chemistry, Faculty of Education, Nile Valley University, Sudan; salahch73@ gmail.com; \\ 3 Department of Chemistry, Faculty of Science and Arts, Al Baha University, Saudi Arabia; monaezo199@ @otmail.com; \\ * Correspondence: mfagery@yahoo.com;
}

Scopus Author ID 57095924800

Received: 28.03.2020; Revised: 8.06.2020; Accepted: 12.06.2020; Published: 17.06.2020

\begin{abstract}
Recently, there is an increasing demand for water due to rapid industrialization and a growing human population. There is a too shortage of available water sources; thus, one option for increasing existing resources is the treatment and reuse of wastewaters. Vinasse poses a long-term risk to public health because of its toxic nature and a huge amount. This study investigates a new prospect of a combination of persulfate (PS)/ peroxymonosulfate (PMS) (activated by Ion (II)) and hydrogen peroxide $\left(\mathrm{H}_{2} \mathrm{O}_{2}\right)$ for reducing total organic carbon (TOC) from vinasse and reuse of treated vinasse as well. Behaviors of $\mathrm{PS} / \mathrm{Fe}(\mathrm{II}) / \mathrm{H}_{2} \mathrm{O}_{2}$ and $\mathrm{PMS} / \mathrm{Fe}(\mathrm{II}) / \mathrm{H}_{2} \mathrm{O}_{2}$ on total organic carbon (TOC) removal are explored by evaluating various effects, including $\mathrm{H}_{2} \mathrm{O}_{2}$ dosage, $\mathrm{Fe}$ (II) dosage, $\mathrm{pH}$ and reaction time. Hydrogen peroxide was used as an oxidation agent to improve the degradation of the organic matter of vinasse. The addition of $\mathrm{H}_{2} \mathrm{O}_{2}$ to PS/ Fe (II) or PMS/ Fe (II) generates highly oxidizing radicals, which enhanced, significantly, the removal of TOC. Both of PS/ Fe (II)/ $\mathrm{H}_{2} \mathrm{O}_{2}$ and PMS/ Fe (II)/ $\mathrm{H}_{2} \mathrm{O}_{2}$ systems favored neutral $\mathrm{pH}$ in removing the organic matter, and they were very active in the first 5 minutes. At the optimum conditions, about $86 \%$ and $83 \%$ of TOC removal were achieved by PS/ Fe (II)/ $\mathrm{H}_{2} \mathrm{O}_{2}$ and PMS/ Fe (II)/ $\mathrm{H}_{2} \mathrm{O}_{2}$, respectively. Therefore, a combination of PS/PMS activated by Fe (II) with $\mathrm{H}_{2} \mathrm{O}_{2}$ can be considered as a capable technique for sugarcane vinasse treatment and allowing to reuse the effluents in many applications.
\end{abstract}

Keywords: Sugarcane vinasse; Sulfate radical; Hydrogen peroxide; Hydroxyl radical; Total organic carbon

(C) 2020 by the authors. This article is an open-access article distributed under the terms and conditions of the Creative Commons Attribution (CC BY) license (https://creativecommons.org/licenses/by/4.0/).

\section{Introduction}

Ethanol distillery wastewater is rated as one of the 17 most polluting industries [1], among them vinasse is considered to be the most hazardous distilleries due to its acidic nature, dark brown liquid with high biological oxygen demand (BOD), and chemical oxygen demand (COD). A considerable amount of vinasse is produced during ethanol manufacturing. Discharging of such large quantities of pollutants affects the environment in a harmful manner $[2]$.

Recently, PS and PMS gained more attention and have been broadly applied to the degradation of organic compounds [3-5]. PS and PMS can be activated by heat, transition metal, electrolysis (EC) and UV to generate sulfate radical (SO4•-) [6-8]. Sulfate radical is a 
strong oxidative character with a redox potential of (2.5-3.1 V), and it has high efficiency of mineralization of organic pollutants [9].

A combination of PS / PMS with other substances in order to enhance the removal of contaminants has been reported several times. For example, using activated carbon as a persulfate/ peroxymonosulfate activator was reported by [10-12]. A combination of ozone with persulfate has been used to enhance the biodegradability of stabilized leachate [13].

Hydrogen peroxide has been used to reduce COD and BOD in a wide variety of industrial and domestic wastewater for many years [14]. Due to oxidation potential (Eo) of $1.76 \mathrm{~V}, \mathrm{H}_{2} \mathrm{O}_{2}$ is capable of oxidizing different organic contaminants and producing environmentally safe products, such as $\mathrm{H}_{2} \mathrm{O}, \mathrm{O}_{2}$, and $\mathrm{OH}-[15]$. Generation of hydroxyl radical (HO) from $\mathrm{H}_{2} \mathrm{O}_{2}$ in water and wastewater treatment systems can be achieved by using various activation techniques such as Fenton's reaction and UV, [16, 17]. Although the $\mathrm{H}_{2} \mathrm{O}_{2}$ reagent can act as a direct oxidant, its performance in the degradation of high organic content is limited [18]. According to many reports, persulfate oxidation in combination with $\mathrm{H}_{2} \mathrm{O}_{2}$ is more efficient for remediation of organic contaminants [19, 20]. Some of the studies have proposed that $\mathrm{H}_{2} \mathrm{O}_{2}$ may act as an activator of persulfate. [19]. So far, the role of $\mathrm{H}_{2} \mathrm{O}_{2}$ in persulfate activation is still vague and poorly demonstrated. In a specific manner, it is not well proved whether $\mathrm{H}_{2} \mathrm{O}_{2}$ certainly activate persulfate or indirectly involve in degradation reactions, such as Fenton-like reaction and consequently improve the degradation efficiency of organic contaminants.

Vinasse contains recalcitrant organic components, such as melanoidins and phenolic compounds [2]. A combination of PS/ $\mathrm{H}_{2} \mathrm{O}_{2} / \mathrm{Fe}$ (II) or PMS/ $\mathrm{H}_{2} \mathrm{O}_{2} / \mathrm{Fe}$ (II) is expecting to generate high amounts of SO.-4 and $\mathrm{OH}^{*}$. The resulting high amounts of free radicals are expected to exhibit relatively high reactivity and became capable of degrading recalcitrant organic compounds.

In past years, countries and international organizations have designed strategies or laws in order to regulate the reuse of treated wastewaters. These laws or guidelines establish the maximum concentrations of contaminants permitted, taking into account the type of water reuse [21]. Among these countries, Sudan established standard characteristics of the reused treated wastewaters. The reuse of treated wastewater depends on the type of wastewater, the characterization of treated wastewater, and the purposes of using. The treated wastewater can be reused for many purposes such as forestry, ornamental, garden, other green spaces, and cleaning of equipment in agricultural or industrial.

Our previous study [22] has demonstrated that only $49 \%$ and $70 \%$ of TOC were removed from vinasse using PS/ Fe (II) and PMS/ Fe (II), respectively. However, the TOC removal extent was inconvenient, suggesting that proper activation of PS and PMS is still required. Therefore, the objective of this study is to propose a new approach of treatment of vinasse by a combination of PS/PMS (activated by ferrous ion) with $\mathrm{H}_{2} \mathrm{O}_{2}$ and reuse the treated vinasse according to Sudanese legislation for wastewater reuse.

\section{Materials and Methods}

\subsection{Chemicals and reagents.}

Hydrogen peroxide $\mathrm{H}_{2} \mathrm{O}_{2}$ (30\%) was obtained from Suprasolv (Germany). Potassium iodide (99\%), $\mathrm{H}_{2} \mathrm{SO}_{4}\left(98 \%\right.$ ), and $\mathrm{FeCl}_{3}$ were obtained from Merck (Germany). $\mathrm{FeSO}_{4} .7 \mathrm{H}_{2} \mathrm{O}$ $(99.5 \%)$, Potassium persulfate (PS) (99\%), and potassium peroxymonosulfate (PMS) were 
purchased from Acros Organics (USA). Sodium hydroxide was obtained from Fluka (Germany). Ammonium molybdate $\left[\left(\mathrm{NH}_{4}\right)_{6} \mathrm{Mo}_{7} \mathrm{O}_{24} \bullet 4 \mathrm{H}_{2} \mathrm{O}\right]$ was obtained from Sigma-Aldrich (USA). Soluble starch was purchased from Sigma-Aldrich (USA). Sodium thiosulfate $\left(\mathrm{Na}_{2} \mathrm{~S}_{2} \mathrm{O}_{3}\right.$ - $\left.5 \mathrm{H}_{2} \mathrm{O}\right)$ was purchased from Sigma-Aldrich (Germany). All reagents were of analytical grade, and only deionized water was used. Ultrapure water was used for the preparation of all aqueous solutions.

\subsection{Characterization of Vinasse.}

The vinasse used in this study was obtained from an ethanol distillery located at White Nile State (Sudan). Vinasse was collected directly after the distillation. Vinasse was, initially, treated by the coagulation-flocculation process at the optimum condition and then treated by PS- Fe (II) or PMS- Fe (II) system as described previously by [22]. The characteristic parameters of raw vinasse and pretreated vinasse are shown in Table 1. The main physicochemical parameters of vinasse were determined according to [23]. The concentrations of $\mathrm{H}_{2} \mathrm{O}_{2}$ were determined according to the method described by Solvay Chemicals [24].

\subsection{Experimental procedures.}

All experiments were performed in a batch mode. All tests were carried out at room temperature in the oxidation reactor. All chemicals and reagents used in the experiments were of analytical grade. Aqueous solutions were prepared in the deionized water (Elga, USA). In order to determine the optimum conditions, we carried out four-stage of experiments as follow:

a) Optimum dosage of PS/Fe (II) or PMS/Fe (II) [22] and different dosages of $\mathrm{H}_{2} \mathrm{O}_{2}$ were added into the oxidation reactor(50-mL glass vials) which contained raw vinasse before the run. The $\mathrm{H}_{2} \mathrm{O}_{2}$ reagent was added gradually to achieve the optimum dosage for the treatment of vinasse.

b) Optimum dosage of $\mathrm{PS} / \mathrm{Fe}$ (II) or PMS/Fe (II) and $\mathrm{H}_{2} \mathrm{O}_{2}$ (obtained from previous oxidation step) were added to the reactor. Then, the immediately different dosage of $\mathrm{Fe}$ (II) was added to the mixture to achieve the optimum molar ratio of $\mathrm{H}_{2} \mathrm{O}_{2} / \mathrm{Fe}$ (II).

c) Under optimum conditions of three previous oxidation steps, $\mathrm{pH}$ values of 3,5, 7 , and 9 were examined and assessed. The $\mathrm{pH}$ value of vinasse was adjusted gradually using sulfuric acid and sodium hydroxide. All runs in steps 1, 2, and 3 were performed for $4 \mathrm{hr}$. of oxidation.

d) The reaction time was studied from $0.083 \mathrm{hr}$. to $24 \mathrm{hr}$. at $\mathrm{pH} 7$.

Table 1. Characteristics of raw and pretreated vinasse.

\begin{tabular}{ccc}
\hline Parameters & Raw vinasse & Pretreated vinasse \\
\hline $\mathrm{pH}$ & 3.5 & - \\
Color & Dark brown & Colorless \\
$\mathrm{TS}$ & $111 \mathrm{mg} / \mathrm{L}$ & - \\
$\mathrm{TDS}$ & $63.8 \mathrm{mg} / \mathrm{L}$ & - \\
$\mathrm{COD}$ & $126 \mathrm{~g} / \mathrm{L}$ & - \\
$\mathrm{BOD}$ & $69.0 \mathrm{~g} / \mathrm{L}$ & - \\
$\mathrm{TOC}$ & $48.000 \mathrm{mg} / \mathrm{L}$ & $134.5 \mathrm{mg} / \mathrm{L}$ \\
$\mathrm{TN}$ & $8.31 \mathrm{mg} / \mathrm{L}$ & - \\
\hline
\end{tabular}

The orbital shaker was used at $150 \mathrm{rpm}$ in all experiments runs. All samples were filtered through a syringe filter with a pore size of $0.45 \mu \mathrm{m}$ prior to analysis. The extent of 
organic matter in vinasse was evaluated by TOC analyses. TOC analyzer (Shimadzu TOC-L) was used to measure TOC concentration in order to monitor the degradation efficiency of organic matter. All samples were immediately analyzed without quenching. The effect of $\mathrm{H}_{2} \mathrm{O}_{2}$ dosage, amount of $\mathrm{Fe}$ (II), $\mathrm{pH}$, and reaction time was studied in detail. All experiments were conducted in triplicates.

\section{Results and Discussion}

\subsection{Effect of $\mathrm{H}_{2} \mathrm{O}_{2}$ concentration.}

To reveal the performance of $\mathrm{H}_{2} \mathrm{O}_{2}$ in enhancing TOC removal from vinasse, the concentration of $\mathrm{H}_{2} \mathrm{O}_{2}$ was varied from $1.44 \mathrm{mM}$ to $5.76 \mathrm{mM}$ and from $0.36 \mathrm{mM}$ to $1.44 \mathrm{mM}$ in PS/Fe (II) and PMS/ Fe(II) systems respectively. As shown in figure 1(a and b), the addition of $\mathrm{H}_{2} \mathrm{O}_{2}$ to the PS/ Fe (II) or PMS/ Fe (II) system improved the organic degradation. In PS/ Fe (II), the addition of $1.44 \mathrm{mM}$ of $\mathrm{H}_{2} \mathrm{O}_{2}$ removed $49 \%$ of TOC. Increasing the dosage of $\mathrm{H}_{2} \mathrm{O}_{2}$ up to $4.32 \mathrm{mM}$, provides the greatest active sites to produce higher amounts of sulfate radicals, and consequently gives better degradation efficiency (60.27\%.). Equations (1) and (2) demonstrate that sulfate radicals were generated in ferrous ion activated systems, and hydroxyl radicals which are produced from the decomposition of $\mathrm{H}_{2} \mathrm{O}_{2}$ increases the concentration of sulfate radicals [25], and accordingly enhancement of TOC removal.

$$
\begin{aligned}
& \mathrm{S}_{2} \mathrm{O}_{8}^{2-}+\mathrm{Fe}^{2+} \rightarrow \mathrm{SO}_{4}{ }^{--}+\mathrm{Fe}^{3+}+\mathrm{SO}_{4}{ }^{2-} \\
& \mathrm{SO}_{4}{ }^{2-}+\mathrm{OH}^{\cdot} \rightarrow \mathrm{SO}_{4}{ }^{--}+\mathrm{OH}^{-}
\end{aligned}
$$

Crimi and Taylor, [26] described the mechanism of the cooperative reaction between PS and $\mathrm{H}_{2} \mathrm{O}_{2}$, which is the decomposition of $\mathrm{H}_{2} \mathrm{O}_{2}$ to form $\mathrm{OH}^{-}$, followed by the activation of the PS to produce $\mathrm{SO}_{4}{ }^{--}$. In addition, many studies demonstrated that the addition of $\mathrm{H}_{2} \mathrm{O}_{2}$ to the PS, can improve the pollutant removal efficiency [27, 28].

In PMS/ Fe (II) system, TOC removal was significantly increased by addition (0.36 $\mathrm{mM}$ ) of $\mathrm{H}_{2} \mathrm{O}_{2}$ Figure $1 \mathrm{~b}$. The increased degradation efficiency is attributed to the producing sulfate radical equation (3). As well as hydroxyl radical, which is formed via decomposition of $\mathrm{H}_{2} \mathrm{O}_{2}$.

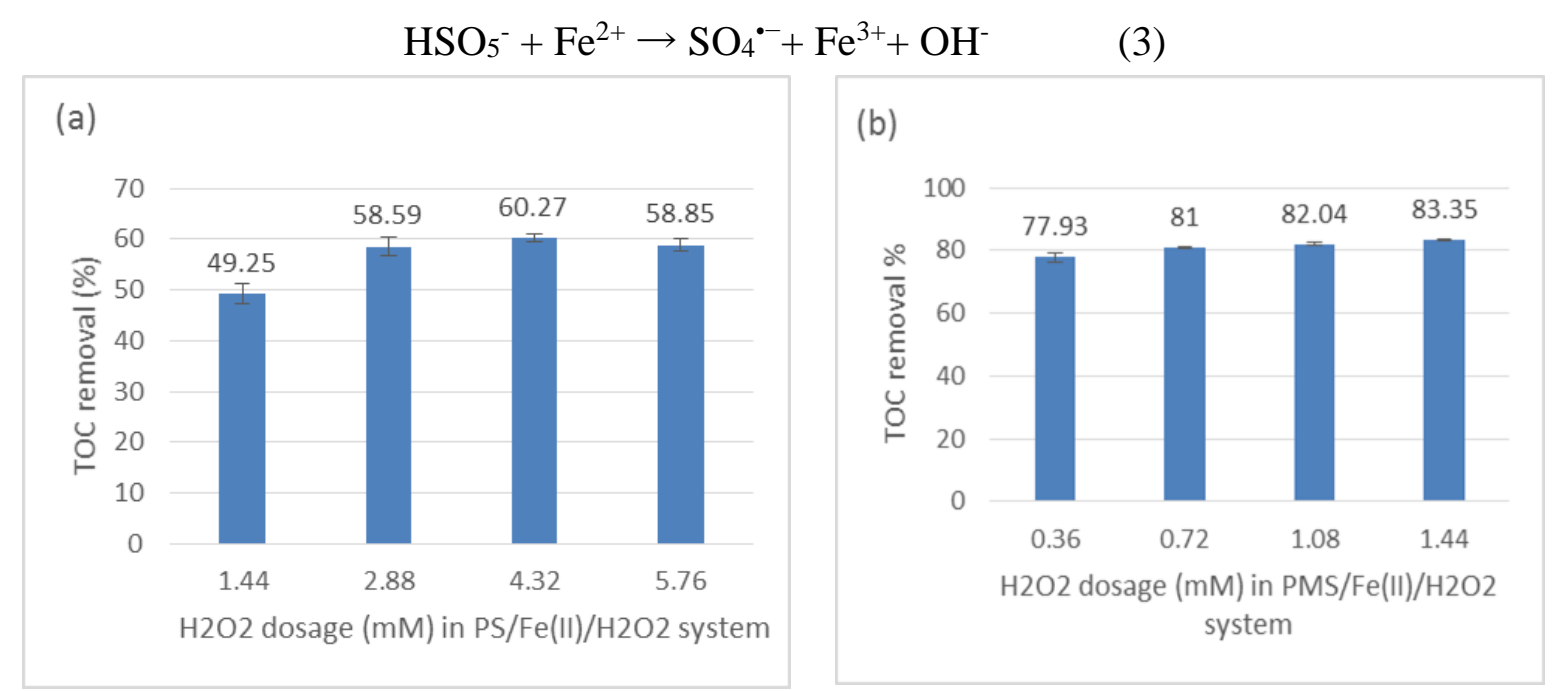

Figure 1. Effect of a: $\mathrm{H}_{2} \mathrm{O}_{2}$ dosage in $\mathrm{PS} / \mathrm{Fe}(\mathrm{II}) / \mathrm{H}_{2} \mathrm{O}_{2}$ system: concentration of $\mathrm{PS}=1.44 \mathrm{mM}$; concentration of $\mathrm{Fe}(\mathrm{II})=0.72 \mathrm{mM} ; \mathrm{pH}=7$; reaction time $=4 \mathrm{~h}$ b: $\mathrm{H}_{2} \mathrm{O}_{2}$ dosage in $\mathrm{PMS} / \mathrm{Fe}(\mathrm{II}) / \mathrm{H}_{2} \mathrm{O}_{2}$ system: concentration of $\mathrm{PMS}=0.36 \mathrm{mM}$; concentration of $\mathrm{Fe}(\mathrm{II})=0.9 \mathrm{mM} ; \mathrm{pH}=7$; reaction time $=4 \mathrm{~h}$. 
Moreover, both sulfate and hydroxyl radicals may have played an important role in enhancing TOC removal. Further addition of $\mathrm{H}_{2} \mathrm{O}_{2}$ demonstrated slight enhancement of TOC removal, from 77.93 to $83.35 \%$. This may be attributed to the very strong and rapid reactions caused by the high oxidant dosages, which may inhibit the generation of hydroxyl radicals and consequently slow down the rate of pollutant degradation. Based on the results and the literature, the mechanism of $\mathrm{PS} / \mathrm{Fe}$ (II)/ $\mathrm{H}_{2} \mathrm{O}_{2}$ and $\mathrm{PMS} / \mathrm{Fe}(\mathrm{II}) / \mathrm{H}_{2} \mathrm{O}_{2}$ processes were illustrated in Figure 2.

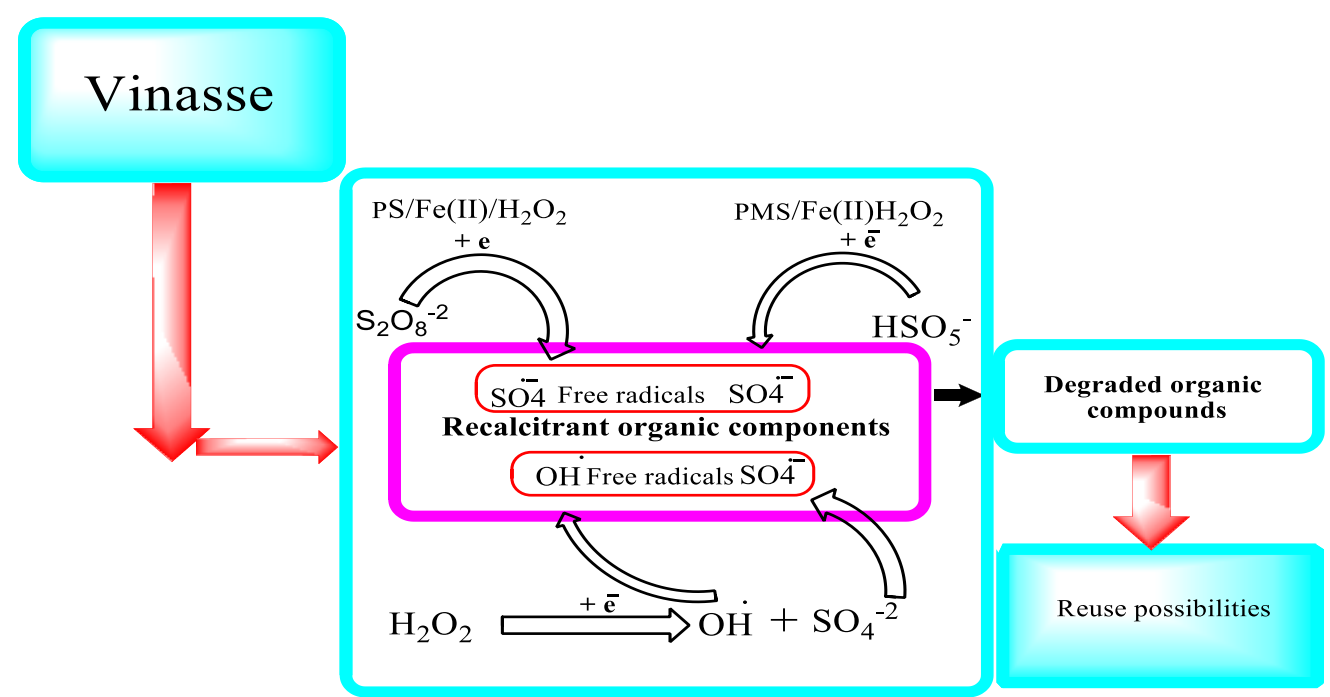

Figure 2. Proposed mechanism of $\mathrm{PS} / \mathrm{Fe}$ (II)/ $\mathrm{H}_{2} \mathrm{O}_{2}$ and $\mathrm{PMS} / \mathrm{Fe}$ (II)/ $\mathrm{H}_{2} \mathrm{O}_{2}$ processes.

\subsection{Effect of $\mathrm{H}_{2} \mathrm{O}_{2} / \mathrm{Fe}$ (II) molar ratio.}

To assess the effect of $\mathrm{Fe}(\mathrm{II})$ concentration, fixed concentrations of $\mathrm{H}_{2} \mathrm{O}_{2}(2.88 \mathrm{mM}$ and $0.72 \mathrm{mM}$ ) were added to $\mathrm{PS} / \mathrm{H}_{2} \mathrm{O}_{2}$ and $\mathrm{PMS} / \mathrm{H}_{2} \mathrm{O}_{2}$ systems respectively, whereas, the concentration of $\mathrm{Fe}$ (II) was varied from 2.88 to $8.64 \mathrm{mM}$ and 0.72 to $2.16 \mathrm{mM}$ for $\mathrm{PS} / \mathrm{H}_{2} \mathrm{O}_{2}$ and $\mathrm{PMS} / \mathrm{H}_{2} \mathrm{O}_{2}$ respectively. Figure $3 \mathrm{a}$ presents TOC removal versus $\mathrm{H}_{2} \mathrm{O}_{2} / \mathrm{Fe}$ (II) molar ratio in $\mathrm{PS} / \mathrm{H}_{2} \mathrm{O}_{2}$ or $\mathrm{PMS} / \mathrm{H}_{2} \mathrm{O}_{2}$ systems. Increasing Fe (II) in $\mathrm{PS} / \mathrm{H}_{2} \mathrm{O}_{2}$ system leads to increase TOC removal, most likely, the added of favorable concentration of Fe (II), resulting in producing a high amount of $\mathrm{HO}$ radical. It may play a significant role in producing more $\mathrm{SO}_{4}{ }^{--}$as well [25]. On the other hand, both $\mathrm{HO}$ and $\mathrm{SO}_{4}{ }^{--}$might concurrently react with organic pollutants and enhanced the degradation performance.

Our result is in good agreement with Lin et al., [29], who proved that both sulfate and hydroxide radicals could work simultaneously for pollutant removal. However, this phenomenon needs further studies to clarify it.

The performance of TOC removal is slightly decreased at a further increase of $\mathrm{Fe}$ (II) dosage. This could be ascribed to an excessive amount of $\mathrm{Fe}^{2+}$, which acts as an intrinsic scavenger of radicals due to the forming of $\mathrm{Fe}^{3+}$ as indicated by equation 4 [30].

$$
\mathrm{Fe}^{2+}+\mathrm{OH}^{\cdot} \rightarrow \mathrm{Fe}^{3+}+\mathrm{OH}^{-}
$$

While in $\mathrm{PMS} / \mathrm{H}_{2} \mathrm{O}_{2}$ system, the addition of $\mathrm{Fe}$ (II) leads to a decrease of TOC removal. This reduction is properly due to the form of some representative reactions expected during the oxidation are as following equations 4,5 , and 6 [31].

$$
\begin{aligned}
& \mathrm{RH}+\mathrm{HO} \rightarrow \mathrm{R} \cdot+\mathrm{H}_{2} \mathrm{O} \\
& \mathrm{R} \cdot+\mathrm{Fe}^{3+} \rightarrow \mathrm{R}^{+}+\mathrm{Fe}^{2+} \\
& \mathrm{Fe}^{2+}+\mathrm{HO} \rightarrow \mathrm{Fe}^{3+}+\mathrm{OH}^{-}
\end{aligned}
$$

Where $\mathrm{RH}=$ organic compound 

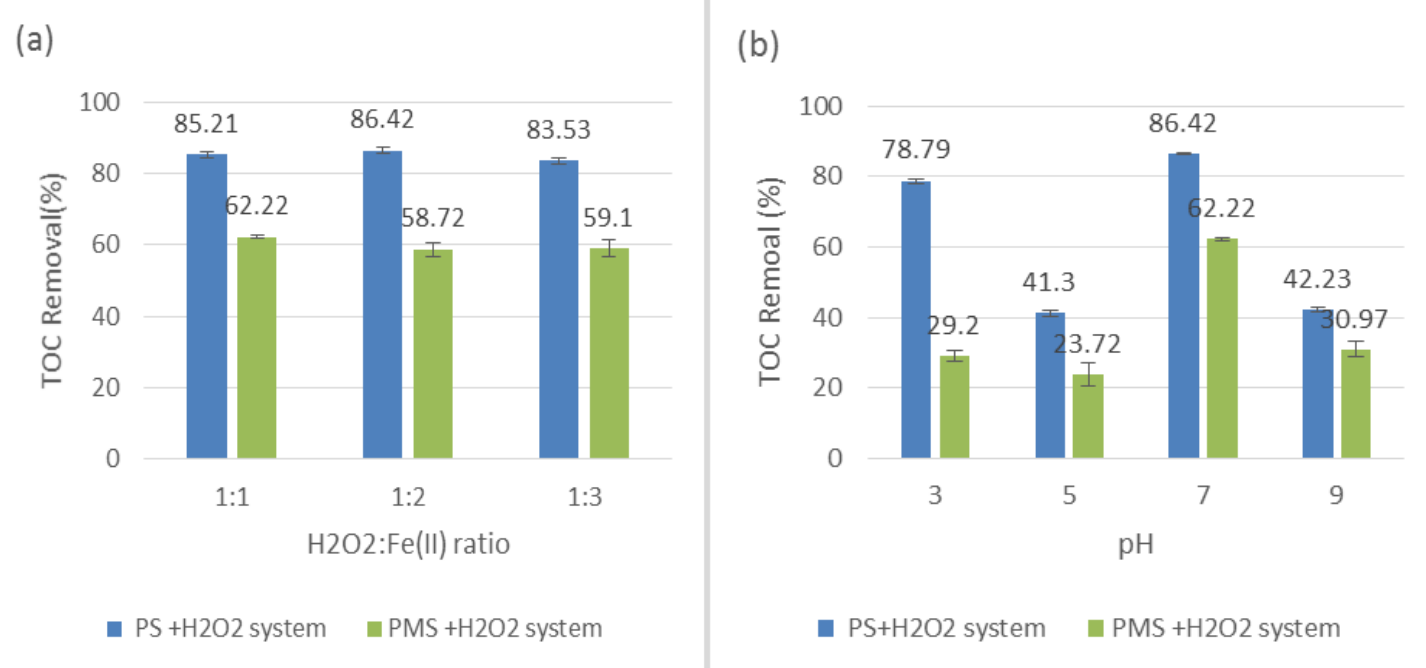

Figure 3. Effect of a; $\mathrm{Fe}$ (II) concentration in PS/ $\mathrm{Fe}(\mathrm{II}) / \mathrm{H}_{2} \mathrm{O}_{2}$ system, conditions: concentration of $\mathrm{H}_{2} \mathrm{O}_{2}=2.88$ $\mathrm{mM}, \mathrm{pH}=7$ and reaction time $=4 \mathrm{~h} ; \mathrm{PMS} / \mathrm{Fe}(\mathrm{II}) / \mathrm{H}_{2} \mathrm{O}_{2}$ system: concentration of $\mathrm{H}_{2} \mathrm{O}_{2}=0.72 \mathrm{mM}, \mathrm{pH}=7$ and reaction time $=4 \mathrm{~h} ; \mathrm{b} ; \mathrm{pH}$ in $\mathrm{PS} / \mathrm{Fe}(\mathrm{II}) / \mathrm{H}_{2} \mathrm{O}_{2}$ system, concentration of $\mathrm{H}_{2} \mathrm{O}_{2}=2.88 \mathrm{mM}, \mathrm{Fe}(\mathrm{II})=\mathrm{mM} 5.76$ and reaction time $=4 \mathrm{~h}$, in $\mathrm{PMS} / \mathrm{Fe}(\mathrm{II}) / \mathrm{H}_{2} \mathrm{O}_{2}$ system conditions: concentration of $\mathrm{H}_{2} \mathrm{O}_{2}=0.72 \mathrm{mM}, \mathrm{Fe}(\mathrm{II})=0.72$ and reaction time $=4 \mathrm{~h}$.

\subsection{The effect of $\mathrm{pH}$.}

The effect of $\mathrm{pH}$ on TOC removal was examined in both acidic and basic ranges over 4 hours. Therefore, values of $3,5,7$, and 9 were taken. The ratios of the $\mathrm{H}_{2} \mathrm{O}_{2}$ to $\mathrm{Fe}$ (II) ratio were fixed in 1:2 and 1:1 for PS/ $\mathrm{H}_{2} \mathrm{O}_{2}$ and PMS/ $\mathrm{H}_{2} \mathrm{O}_{2}$ systems, respectively. As shown in figure $3 b$, maximum removal of TOC $86.4 \%$ for $\mathrm{PS} / \mathrm{H}_{2} \mathrm{O}_{2}$ and $62.2 \%$ for $\mathrm{PMS} / \mathrm{H}_{2} \mathrm{O}_{2}$ were achieved at $\mathrm{pH}$ 7. Most researchers reported that the PS, PMS, and $\mathrm{H}_{2} \mathrm{O}_{2}$ achieve the highest efficiency of organic pollutants degradation at low $\mathrm{pH}$, due to the formation of $\mathrm{SO}_{4}{ }^{-}$and $\mathrm{HO}$. radicals through acid-catalysis reaction [27,32]. In contrast to these reports, the improvement of TOC removal in a neutral medium may be explained by the formation of some complexes due to some reactions between Fe (II) and soluble compounds in the vinasse, such as polyaromatic and polyphenols [33]. These complexes prevent the oxidation of $\mathrm{Fe}$ (II) to $\mathrm{Fe}$ (III) and consequently enhance the TOC removal.

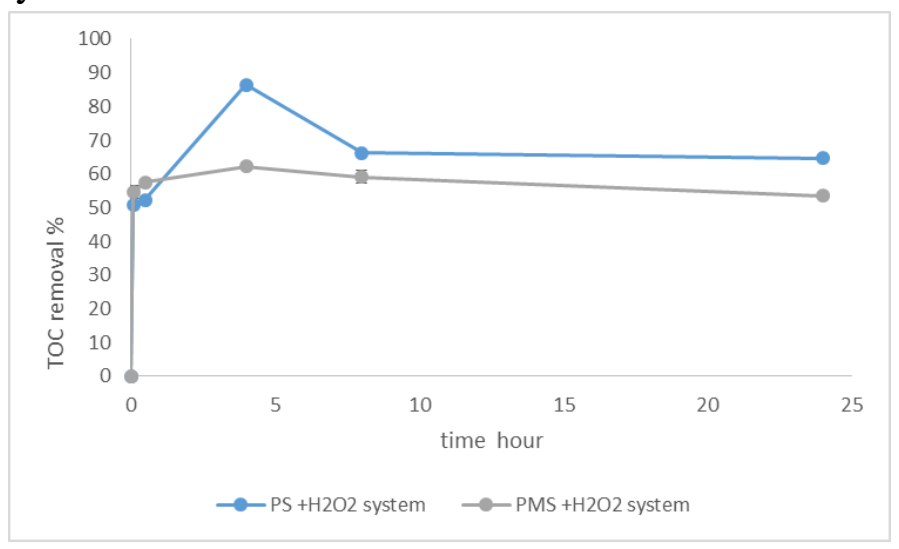

Figure 4. The effect of reaction time in $\mathrm{PS} / \mathrm{Fe}(\mathrm{II}) / \mathrm{H}_{2} \mathrm{O}_{2}$ system, concentration of $\mathrm{H}_{2} \mathrm{O}_{2}=2.88, \mathrm{Fe}(\mathrm{II})=5.76$ and $\mathrm{pH}=7$, in $\mathrm{PMS} / \mathrm{Fe}(\mathrm{II}) / \mathrm{H}_{2} \mathrm{O}_{2}$ system conditions: concentration of $\mathrm{H}_{2} \mathrm{O}_{2}=0.72 \mathrm{mM}, \mathrm{Fe}(\mathrm{II})=1.44 \mathrm{mM} 0.72$ and $\mathrm{pH}$ $=7$.

\subsection{The effect of reaction time.}

To observe the effect of reaction time, the oxidation experiments were carried out for $0.083,0.5,4,8$, and 24 hours on the pretreated vinasse. The results indicated that the TOC 
removal increased significantly for the first 5 min for both $\mathrm{PS} / \mathrm{Fe}$ (II)/ $\mathrm{H}_{2} \mathrm{O}_{2}$ and PMS/ Fe (II) $/ \mathrm{H}_{2} \mathrm{O}_{2}$ systems, as indicated in figure 4 . When the reaction times increased from 5 min to 4 h TOC removal increased significantly, from 50 to $86.42 \%$ and 54.6 to $62.2 \%$ for PS/ Fe (II) $/ \mathrm{H}_{2} \mathrm{O}_{2}$ and $\mathrm{PMS} / \mathrm{Fe}$ (II) $/ \mathrm{H}_{2} \mathrm{O}_{2}$ systems respectively. After $24 \mathrm{~h}$ of reaction time, the TOC removal decrease to 64.7 and $53.53 \%$ in both systems, respectively. This might be due to the reforming of some of the organic compounds.

\section{Conclusions}

This study has focused on the degradation of the organic matter from vinasse through a combination of PS/PMS mediated activation $\mathrm{Fe}$ (II) with $\mathrm{H}_{2} \mathrm{O}_{2}$ and reused the treated vinasse for the first time. The effects of $\mathrm{H}_{2} \mathrm{O}_{2}$, a further dosage of $\mathrm{Fe}$ (II), $\mathrm{pH}$, and reaction time were studied. At higher $\mathrm{H}_{2} \mathrm{O}_{2}$ dosage, a significant amount of radicals were produced, leading to a removal of $83.35 \%$ of TOC in PMS/ Fe (II)/ $\mathrm{H}_{2} \mathrm{O}_{2}$ system. In PS/ Fe (II)/ $\mathrm{H}_{2} \mathrm{O}_{2}$ system, at optimum experimental conditions of $\mathrm{H}_{2} \mathrm{O}_{2}$ and $\mathrm{Fe}$ (II), $86 \%$ of TOC removal was achieved. Summing up the results, it can be concluded that $\mathrm{PS} / \mathrm{H}_{2} \mathrm{O}_{2} / \mathrm{Fe}$ (II) and $\mathrm{PMS} / \mathrm{H}_{2} \mathrm{O}_{2} / \mathrm{Fe}$ (II) were capable of mineralizing the recalcitrant organic compounds in vinasse and allowing reuse the effluents in irrigation of plenteous trees and green areas, side of roads outside cities according to Sudanese legislation for wastewater reuse.

\section{Funding}

This research received no external funding.

\section{Acknowledgments}

\section{The authors wish to thank the Department of Chemistry, University of Malaya, for supporting this research and Kenana Sugar Company for providing vinasse samples.}

\section{Conflicts of Interest}

The authors declare no conflict of interest.

\section{References}

1. Satyawali, Y.; Balakrishnan, M. Wastewater treatment in molasses-based alcohol distilleries for cod and color removal: a review. J Environ Manage 2008, 86, 481-497, https://doi.org/10.1016/j.jenvman.2006.12.024.

2. Joberson, A.J.; Yago, A.V.; Ianny, A.C.; Débora, S.V.; Mario, M.A.; Torres, H.N.; Ram, N.B.; Álvaro, S.L.; Ranyere, L.S.; Luiz, F.R. F. Sequential degradation of raw vinasse by a laccase enzyme producing fungus Pleurotus sajor-caju and its ATPS purification. Biotechnol Rep 2020, 25, https://doi.org/10.1016/j.btre.2019.e00411.

3. Jianlong, W.; Shizong, W. Activation of persulfate (PS) and peroxymonosulfate (PMS) and application for the degradation of emerging contaminants. Chem. Eng. J 2018, 334, 1502-1517, https://doi.org/10.1016/j.cej.2017.11.059.

4. Zhihua, S.; Shiyao L; Haojie, D.; Yunhua, Z.; Xuxu, W.; Huanfang, L.; Qin, Z. Chun Zhao. Electrochemical $/ \mathrm{Fe} 3+/$ peroxymonosulfate system for the degradation of Acid Orange 7 adsorbed on activated carbon fiber cathode. Chemosphere 241, https://doi.org/10.1016/j.chemosphere.2019.125125.

5. Ahmadi, S.; Lgwegbe, C. A.; Rahdar, S. The application of thermally activated persulfate for degradaition of acid blue 92 in aqueous solution. Int. J. Ind. Chem 2019, 1-12, https://doi.org/10.1007/s40090-019-01881. 
6. Manz, K.E.; Carter, K.E. Degradation of hydraulic fracturing additive 2-butoxyethanol using heat activated persulfate in the presence of shale rock. Chemosphere 2018, 206, 398-404, https://doi.org/10.1016/j.chemosphere.2018.05.007.

7. Arellano, M.; Sanroman, M.A.; Pazos, M. Electro-assisted activation of peroxymonosulfate by iron-based minerals for the degradation of 1-butyl-1-methylpyrrolidinium chloride. Separ. Purif. Technol 2019, 208, 34-41, https://doi.org/10.1016/j.seppur.2018.05.028.

8. Zhang, X.; Yao, J.; Zhao, Z.; Liu, J. Degradation of haloacetonitriles with UV/ peroxymonosulfate process: degradation pathway and the role of hydroxyl radicals.Chem. Eng. J 2019, 364, 1-10, https://doi.org/10.1016/j.cej.2019.01.029.

9. Guo, D.F.; Dionysios, D. D.; Yu, W.; Souhail, R.A.; Dong, M.Z. Sulfate radical-based degradation of polychlorinated biphenyls: Effects of chloride ion and reaction kinetics. J Hazard Mater 2012, 227-228, 394-401, https://doi.org/10.1016/j.jhazmat.2012.05.074.

10. Forouzesh, M.; Ebadi, A.; Aghaeinejad, M.A. Degradation of metronidazole antibiotic in aqueous medium using activated carbon as a persulfate activator. Separ. Purif. Technol 2019, 210, 145-151, https://doi.org/10.1016/j.seppur.2018.07.066.

11. Liu, Z.; Ding, H.; Zhao, C.; Wang, T.; Wang, P.; Dionysiou, D.D. Electrochemical activation of peroxymonosulfate with ACF cathode: kinetics, influencing factors, mechanism, and application potential. Water Res 2019, 159, 111-121, https://doi.org/10.1016/j.watres.2019.04.052.

12. Fuzhen, L.; Yin, X.; Baisong, Z.; Yalu, L.; Hui, Z. Heterogeneous degradation of organic contaminant by peroxydisulfate catalyzed by activated carbon https://doi.org/10.1016/j.chemosphere.2019.124611.

cloth. Chemosphere 2019, 238,

13. Abu amr, S.S.; Aziz, H.A.; Adlan, M.N.; Alkaseeh, J.M. Effect of ozone and ozone/persulfate processes on biodegradable and soluble characteristics of semi-aerobic stabilized leachate. J. Environ. Prog. Sustain. Energy 2014, 33, 184-191, https://doi.org/10.1002/ep.11779.

14. Mohamed, K. Chemical oxidation with hydrogen peroxide for domestic wastewater treatment. Chem. Eng. J 2006, 119, 161-165, https://doi.org/10.1016/j.cej.2006.03.022.

15. Bautista, P.; Mohedano, A.F.; Casas, J.A.; Zazo, J.A.; Rodriguez, J.J. An overview of the application of Fenton oxidation to industrial wastewaters treatment. J.Chem. Technol. Biot 2008, 83, 1323-1338, https://doi.org/10.1002/jctb.1988.

16. De Heredia, J B.; Torregrosa, J.; Dominguez, J.R.; Partido, E. Degradation of wine distillery wastewaters by the combination of aerobic biological treatment with chemical oxidation by Fenton's reagent. Water Sci Technol 2005, 51, 167-174, https://doi.org/10.2166/wst.2005.0021.

17. Lushi, L.; Bo, Y.; Shaodong, H.; Jingyun, F.; Shuwen, Y.; Weihua, S. Kinetic Study of Hydroxyl and Sulfate Radical-Mediated Oxidation of Pharmaceuticals in Wastewater Effluents. Environ. Sci. Technol 2017, 51, 2954-2962, https://doi.org/10.1021/acs.est.6b05536.

18. Torres-Luna, J.R.; Ocampo-Perez, R.; Sanchez-Polo, M.; Rivera U.; Velo-Gala, L.A. Bernal-Jacome. Role of $\mathrm{HO}_{-}$and $\mathrm{SO}_{4} 4$ radicals on the photodegradation of remazol red in aqueous solution. Chem. Eng. J 2013, 223, 155-163, https://doi.org/10.1016/j.cej.2013.02.127.

19. Dan, Z.; Xiaoyong, L.; Xiulan, Y.; Scott, G. H.; Tuanyao, C.; Huan, T. Effect and mechanism of persulfate activated by different methods for PAHs removal in soil. J Hazard Mater 2013, 254-255, 228-235, https://doi.org/10.1016/j.jhazmat.2013.03.056.

20. Ahmed, H.; Hilles, S.S.; Abu Amr, R.A.; Hussein, O.D. El-Sebaie, A.I.A. Performance of combined sodium persulfate $/ \mathrm{H}_{2} \mathrm{O}_{2}$ based advanced oxidation process in stabilized landfill leachate treatment. J. Environ. Manage 2016, 166, 493-498, https://doi.org/10.1016/j.jenvman.2015.10.051.

21. Jorge, R.C.; Sónia, I.M.; Marco, S.L.; José, R.F.; Pedro, B.T.; Sampaio, A.; José, A.P. Disinfection of simulated and real winery wastewater using sulphate radicals: Peroxymonosulphate/transition metal/UV-A LED oxidation. J Clean Prod 2017, 149, 805-817, https://doi.org/10.1016/j.jclepro.2017.02.135.

22. Fagier, M.A.; Ali, E.A Kheng, T.S.; Abas, M.R.B. Mineralization of organic matter from vinasse using physicochemical treatment coupled with $\mathrm{Fe}^{2+-}$ activated persulfate and peroxymonosulfate oxidation. Int. J. Environ. Sci. Technol 2016, 13, 1189-1194, https://doi.org/10.1007/s13762-016-0963-x.

23. Clesceri, LS.; Greenberg, A.E.; Eaton, A.D. Standard methods for the examination of water and wastewater. 20th edn. American Public Health Association (APHA), Washington, 1998.

24. www.solvaychemicals.us. 2004.(12/8/2015)

25. Ahmed, H.; Hilles, S.S.; Abu Amr, R.A.; Hussein, A.I.; Arafa, O.D. Performance of combined sodium persulfate $/ \mathrm{H}_{2} \mathrm{O}_{2}$ based advanced oxidation process in stabilized landfill leachate treatment. Waste Manag 2015, 44, 172-177, https://doi.org/10.1016/j.jenvman.2015.10.051.

26. Crimi, M.L.; Taylor, J. Experimental evaluation of catalyzed hydrogen peroxide and sodium persulfate for destruction of BTEX contaminants. Soil Sediment. Contam 2007, 16, 29-45, https://doi.org/10.1080/15320380601077792.

27. J. Méndez-Díaz, M.; Sánchez-Polo, J.; Rivera-Utrilla, S.; Canonica, U. Von, G. Advanced oxidation of the surfactant SDBS by means of hydroxyl and sulphate radicals. Chem. Eng. J 2010, 163, 300-306, https://doi.org/10.1016/j.cej.2010.08.002. 
28. Ferrarese, E.; Andreottola, G.; Aura Oprea, I. Remediation of PAH-contaminated sediments by chemical oxidation. J Hazard Mater 2008, 152, 128-139, https://doi.org/10.1016/j.jhazmat.2007.06.080.

29. Heng, L.; Jie, W.; Hui, Z. Degradation of clofibric acid in aqueous solution by an EC/Fe3+/PMS process. Chem. Eng. J 2014, 244, 514-521, https://doi.org/10.1016/j.cej.2014.01.099.

30. Waldemer, R.H.; Tratnyek, P.G. Kinetics of contaminant degradation by permanganate. Environ Sci Technol 2006, 40, 1055-1061, https://doi.org/10.1021/es051330s.

31. Prakash. N.; Garg, A. Comparative performance evaluation of physicochemical treatment processes for simulated dairy wastewater. Int. J. Environ. Sci. Technol 2016, 13, 2675-2688, https://doi.org/10.1007/s13762-016-1099-8.

32. Zhang, Q.; Chen, J.; Dai, C. Degradation of carbamazepine and toxicity evaluation using the UV/persulfate process in aqueous solution. J Chem Technol Biotechnol 2015, 90, 701-708, https://doi.org/10.1002/jctb.4360.

33. José, M.S.; Martínez Carballo, E.M.; Belén, M.; José, M.D. Characterization of vinasses from five certified brands of origin (CBO) and use as economic nutrient for the xylitol production by Debaryomyces hansenii. Bioresour Technol 2010, 101, 2379-2388, https://doi.org/10.1016/j.biortech.2009.11.015. 